\title{
Trends of Possible 2020 Seoul Tracking Fire
}

\author{
Hong-Ki Park \\ Dept. of Electrical and Computer Engineering, University of Seoul, Seoulsiripdaero, \\ Dongdaemun-gu, Seoul, Korea \\ krosa777@daum.net
}

\begin{abstract}
In Seoul, tracking fires have been on the rise among fires in commercial and residential buildings for five years. When wires or electrical equipment in old buildings contain moisture from the atmosphere and dust or other objects are attached to conductors, micro discharge progresses gradually, creating challenging passages on the surface to track where fires occur. In this paper, it can be represented as the annual deterioration phenomenon of challenging clause softener in the use of environmental aged electrical equipment. The purpose was to analyze the increase and decrease of electrical fires after 2020 by identifying the insulation and conductivity of the VCTF wires used in aged electricity facilities. Experiments on electrical wires under the environment. Compared to simple correlation, Seoul since 2020.Under the environment, we will predict the increase and decrease of tracked electric fires and use them as basic data for future composite disaster models.
\end{abstract}

Keywords: Tracking electric fires, Electrical facilities aging, Insulation, Degradation, VCTF

\section{Introduction}

According to the Seoul Institute's latest report, "How many fires occur in Seoul?" a total of 28,000 fires have been reported in Seoul over the past five years (2010-2014), with an average of 5,600 fires occurring annually. Looking at the causes of electric fires from 2013 to 2013, the unidentified short insulation and overload tracking have characteristics that are 2.5 times higher than those of advanced countries.

\section{Tracking fire change}

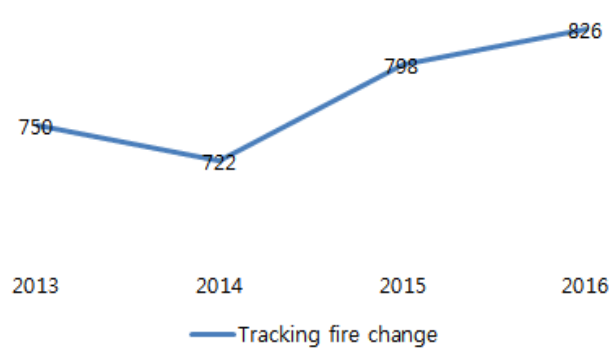

Figure 1. Tracking fire change

Article history:

Received (October 14, 2019), Review Result (December 7, 2019), Accepted (January 10, 2020) 
In this paper, we want to draw out concrete changes in the external environment, [1] focusing on the tracking fire hazard of aged electrical facilities. After establishing the basic content for tracking fires, which are the main phenomena of electrochemical, we want to link the relationship with the increase in tracking fire phenomena by comparing the data of aggregated electrical fires with the data of external environmental changes that can put a load on the tracking phenomena. To this end, the Seoul Metropolitan Government will analyze and compare the 2012-2016 fire increase statistics, fine dust increase phenomenon data and the Seoul Metropolitan Government's climate change data.

Table 1. Seoul 2012.05.01. 2016.04.40 the number of fire incidents [2]

\begin{tabular}{|c|c|c|c|c|}
\hline & $\begin{array}{c}2012.05 .01 \\
2013.05 .01\end{array}$ & $\begin{array}{c}2013.05 .01 \\
2014.05 .01\end{array}$ & $\begin{array}{c}2014.05 .01 \\
2015.05 .01\end{array}$ & $\begin{array}{c}2015.05 .01 \\
2016.04 .30\end{array}$ \\
\hline $\begin{array}{c}\text { Ground } \\
\text { fault }\end{array}$ & 450 & 430 & 381 & 301 \\
\hline Poor contact & 985 & 946 & 904 & 941 \\
\hline $\begin{array}{c}\text { Insulation } \\
\text { degradation }\end{array}$ & 2508 & 2544 & 2459 & 2297 \\
\hline $\begin{array}{c}\text { Over } \\
\text { current }\end{array}$ & 1149 & 1001 & 984 & 870 \\
\hline $\begin{array}{c}\text { Crimp } \\
\text { damage }\end{array}$ & 679 & 602 & 608 & 609 \\
\hline $\begin{array}{c}\text { Interlayer } \\
\text { short circuit }\end{array}$ & 112 & 102 & 94 & 101 \\
\hline Tracking & 750 & 722 & 798 & 826 \\
\hline Half line & 162 & 153 & 159 & 171 \\
\hline Unidentified & 2668 & 2409 & 2363 & 2178 \\
\hline Etc & 958 & 835 & 790 & 713 \\
\hline Sum & 10441 & 9744 & 9540 & 9007 \\
\hline
\end{tabular}

\section{Environmental factors}

Experiment with aged $0.75 \mathrm{SQ} \mathrm{mm} 2$ insulated wire samples sampled at the site and new $0.75 \mathrm{SQ} \mathrm{mm} 2$ insulated wire samples under the same conditions. How the load changes after 10 minutes were compared and observed.

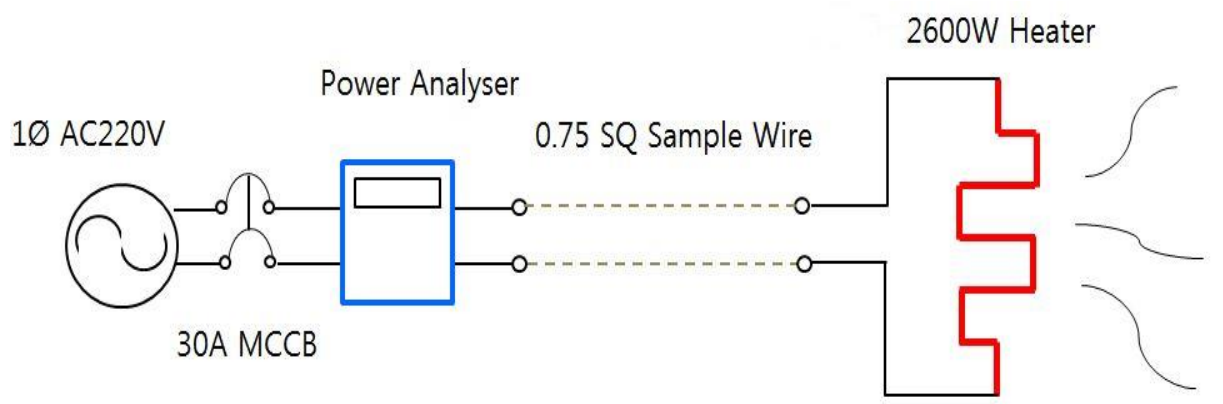

Figure 2. Experiment circuit of old wire heating 


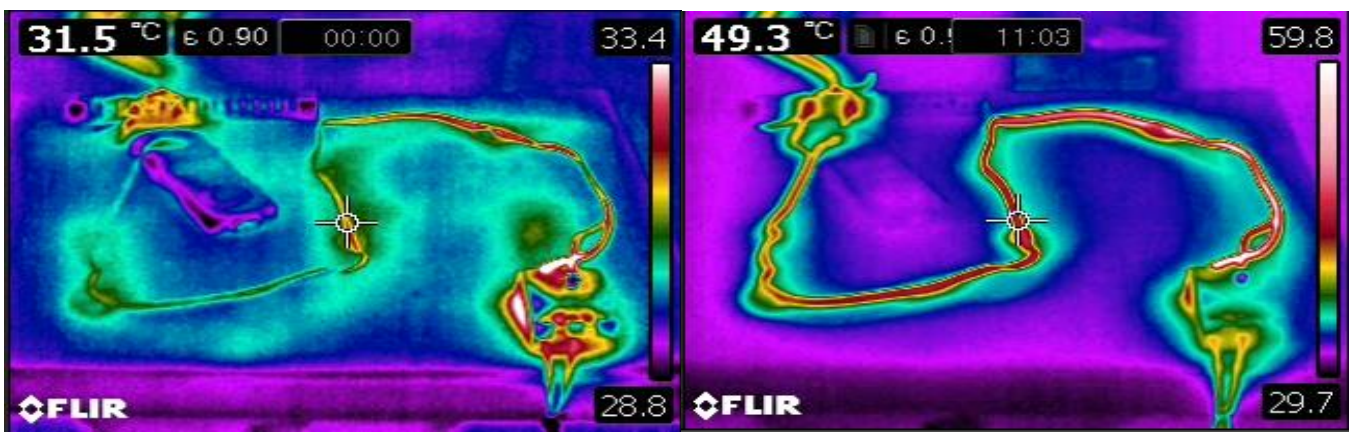

Figure 3. Old heat wire heat image change, previous (left) / after (right)

It was possible to verify that the temperature of the entrance to the electric heat at $18.2^{\circ} \mathrm{C}$ increased by a difference of $26.4^{\circ} \mathrm{C}$ under the load conditions of $600 \mathrm{~W}$.

\section{Temperature Characteristics in Seoul}

According to the characteristics of the Seoul Metropolitan Government, the number of insulation deterioration cases decreased 8.42 percent from 2,508 to 2,297 in the period of 2012.05 to 7,50 in the period of April 2016 [3]. The number of fires caused by tracking has increased by 101.053 percent from 2,012.01 (750) to 2,014.30 [4].

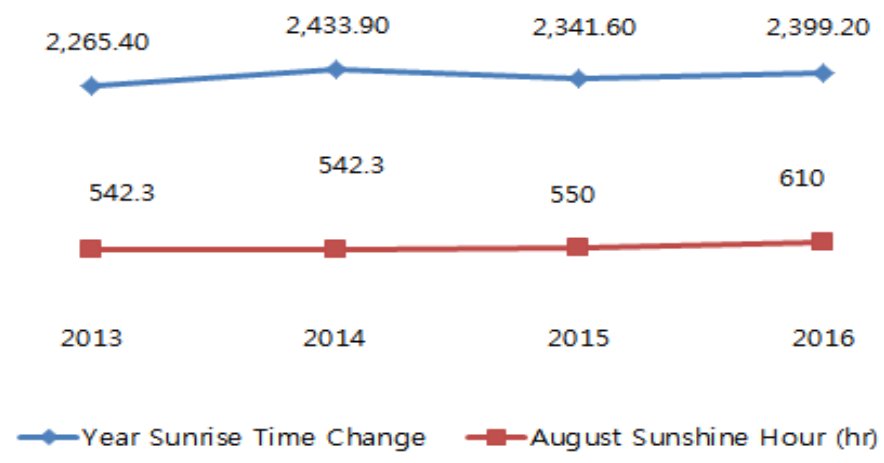

Figure 4. 2013-2016 Sunrise time increase and tracking fire [5]

The 2013-2016 tracking fires were able to identify similarities in the pattern of increasing the annual sunlight time from 2,265.40 to 2,399.20 over the same period, from 7,750 a year to 826 a year. If the change in August temperature during which the heatwave lasts for the same period is confirmed, there is a similar pattern with a $2.3{ }^{\circ} \mathrm{C}$ increase from $25.7{ }^{\circ} \mathrm{C}$ to $28{ }^{\circ} \mathrm{C}$ in 2016, and a pattern of increase in daylight hours and temperature [6]. Considering the nature of tracking progressively, statistics show the similarity between the major environmental change characteristics and the increase in tracking fires [7].

The average annual average of 561.1 hours between 2013 and 2016 for the summer months. It has increased by 1.1238 times per year for 4 years to 610 hours in 2016 [8].

It is increased by 16.795 hours per year by $3.095 \%$ per year. Over the past four years, 67.2 hours of sunshine per year has been increasing. During the same period, the number of tracking fires has risen +11.053 percent from 750 to 828 , increasing +2.763 percent. 


\section{National temperature characteristics}

The national average temperature during the summer season is $24.8^{\circ} \mathrm{C}, 1.2^{\circ} \mathrm{C}$ higher than the average temperature of $23.6^{\circ} \mathrm{C}$. Average highs and lows are $9.7{ }^{\circ} \mathrm{C}$ and $20.9{ }^{\circ} \mathrm{C}$, respectively, which tend to be $1.3{ }^{\circ} \mathrm{C}$ and $1.2{ }^{\circ} \mathrm{C}$ higher than usual. August 2016 marks the largest record since $28^{\circ} \mathrm{C}$ recorded $27.8^{\circ} \mathrm{C}$ in 1943 .

Table 2. Temperature characteristics

\begin{tabular}{|l|l|l|l|}
\hline \multicolumn{2}{|l|}{ Seoul } \\
\hline \multicolumn{2}{|c|}{ Heat days } & \multicolumn{2}{c|}{ Tropical days } \\
\hline 1994 year & 29 & 1994 & 36 \\
\hline 2016 year & 24 & 2016 & 32 \\
\hline 2000 year & 18 & 2013 & 23 \\
\hline
\end{tabular}

The number of days of summer heat wave in Seoul recorded for tropical nights on Monday, with average tropical nights hitting 6.6 days and tropical nights at 8.4 days. The table below shows that the number of days in Seoul has increased from 22.4 days and 10.8 days, respectively, in 2016 [8].

\section{Precipitation}

The precipitation in Seoul in the 2000s (2001-2010) was $1550.2 \mathrm{~mm}$, down from 1,231.5 $\mathrm{mm}$ in the 1970s (1971-1980). Precipitation in 2014 tends to decrease to nearly half the level of $52 \%$ compared to $1550.2 \mathrm{~mm}$ in the previous year $2001 \mathrm{~mm}$.

Table 3. Seoul has the lowest precipitation since 1992

\begin{tabular}{|c|c|c|c|c|c|}
\hline Year & 2015 & 1994 & 1982 & 2014 & 2016 \\
\hline Minimum precipitation & 397.9 & 457.2 & 467.0 & 478.8 & 479.7 \\
\hline Tranking & 1 & 2 & 3 & 4 & 5 \\
\hline
\end{tabular}

With $28.9 \mathrm{~mm}$ of precipitation in Seoul, the city recorded the lowest rainfall of 27.3 percent compared to the average year of $105.9 \mathrm{~mm}$. Based on the August 2016 heat wave, precipitation has been $671 \mathrm{~mm}$ since 1973, indicating a sharp drop in precipitation in 2015.In terms of the minimum amount of precipitation in the summer months since 1994, the first place is $397.9 \mathrm{~mm}$ in 2015 , second place $457.2 \mathrm{~mm}$ in 1994 , third place $467.0 \mathrm{~mm}$ in 1982 , fourth place $478.8 \mathrm{~mm}$ in 2014 and fifth place in $2016479.7 \mathrm{~mm}$ [9].

Table 4. $2013 \sim 2020$ Tracking fire in Seoul and main environment Simple correlation analysis

\begin{tabular}{|c|c|c|}
\hline & Fire change & Change in dayligt \\
\hline Fire change & 1 & 1 \\
\hline Change in daylight & 0.868922 & Average temperature \\
\hline & Fire change & - \\
\hline Fire change & 1 & \\
\hline
\end{tabular}




\begin{tabular}{|c|c|c|}
\hline Average temperature & -0.023782 & 1 \\
\hline & Fire change & Maximum temperature \\
\hline Fire change & 1 & 1 \\
\hline Maximum temperature & 0.94564 & Precipitation \\
\hline & Fire change & - \\
\hline Fire change & 1 & August sunrise time \\
\hline Precipitation & -0.312203 & - \\
\hline & Fire change & 1 \\
\hline Fire change & 1 & \\
\hline August sunrise time & 0.957329 & \\
\hline
\end{tabular}

\section{Conclusion}

Through a simple correlation, we attempted to predict the possible increase and relationship of tracking fires between 2017 and 2020 and the following conclusions were obtained. By using VCTF $0.75 \mathrm{SQmm} 2$ of the wires for fluorescent lights that are actually exposed to the outside world, the analysis was made to correlate with the basic data for changes in the climate environment up to 2016 and to predict the possibility of an increase in tracking fires after 2010.

First, based on actual external exposure wires, we compared the change in thermal imaging temperature in a similar overload environment after 10 minutes. Second, $18.2^{\circ} \mathrm{C}$ pre-heated entrance with initial wire temperature under the load conditions of $2,600 \mathrm{~W}$ could be increased by a difference of $26.4^{\circ} \mathrm{C}$. Third, the increase in tracking fires was seen in August as an increase in the number of tracking fires and an increase in tracking fires. As of 2013-2016, tracking fires are increasing at an annual rate of $11.053 \%$, and the average monthly sunshine time during the heatwave period is increasing at $12.38 \%$ over four years.

Second, based on the actual external exposure wires, we compared the change in thermal imaging temperature in a similar overload environment after 10 minutes. We could see that there was a continuous solar time, or heatwave, in changing the environment.

Based on these results, if the heat wave duration, which is a part of the environment, is extended, the possibility of tracking electric fires increasing for wire use older than 25 years can be seen. To prevent tracking fires, it is believed that regulations on the criteria and timing of replacement of exposed wires of buildings that have aged for more than 15 years should be legislated and replaced by a mandatory step by step. Further research is needed on overloading experiments on insulation strength of old wires in the future.

\section{References}

[1] Cha S.W., Park D.W., Cha H. K., Cho H. E., and Kil G. S., "Phase distribution of partial discharge pulses for tracking defect in a CNCO-W cable," 2011 Proceedings of the Korean Society of Marine Engineers Conference, Korean Society of Marine Engineers, pp.185, (2011)

[2] Seoul National Emergency Management Agency Statistics, 2012.05.01-2016.04.30

[3] Weather Service Seoul, https://www.weather.go.kr/w/index.do 2012.05.01 - 2016.04.30

[4] G.U. Lim Y.H., Nam S.Y., Jang S.J., Jeong Y.S., and Yong, S.Y., "Sediment and woody debris trap effect of h-type slit dam with model experiment," 2010 Summer conference of Korean Forest Society, Korean Forest Society, pp.349-350, (2010) 
[5] Kim J.H., Jeon G.U., Seo J.I., Yoon J.U., Kwon S.M., and Kim Y.R., "Effects of float-board screen for catching drift woods and debris flows in urban areas," 2013 Summer conference of Korean Forest Society, Korean Forest Society, pp.913-914, (2013)

[6] Kim Y.I. and Paik J.C., "Experiments on debris flows in a rectangular channel," 2010 Korea Society of Civil Engineers CIVIL EXPO, Korea Society of Civil Engineers, pp.279-282, (2010)

[7] Kim Y.I. and Paik, J.C., "Experimental investigation of depositional patterns of debris flow," 2011 conference of Korea Water Resources Association, Korea Water Resources Association, pp.38-42, (2011)

[8] Regional Climate Change Report (Seoul) 12th, 2011 Korea Meteorological Administration

[9] The Seoul Institute, "How many fires does Seoul fire?" Seoul Info Graphics, vol.165, pp.1, (2015)

\section{Authors}

\section{Hong-Ki Park}

Department of Electrical and Computer Engineering, University of Seoul, Seoul siripdaero. Ph.D. Candidate in Ergonomics (Instrumentation Control Network) Lab. 